\title{
A OITAVA TESE DE ABRIL DE LÊNIN: SOCIALISMO, SOVIETES E A CENTRALIZAÇÃO DA PRODUÇÃO
}

\author{
LA OCTAVA TESIS DE ABRIL DE LENIN: SOCIALISMO, SOVIETES Y LA \\ CENTRALIZACIÓN DE LA PRODUCCIÓN
}

\section{LENIN'S EIGHT APRIL THESIS: SOCIALISM, SOVIETS AND CENTRALIZATION OF PRODUCTION}

DOI: http://dx.doi.org/10.9771/gmed.v12i2.37594

\author{
Ana Carolina Marra de Andrade ${ }^{1}$ \\ Júlio César Villela da Motta Filho²
}

Resumo: No presente artigo, pretendemos realizar uma análise da oitava tese de abril, levando em consideração o contexto no qual ela foi escrita. Para isso, buscamos utilizar o método da análise imanente ou estrutural chasiniana para compreendermos os principais conceitos tratados por Lênin neste ponto. Assim, propõe-se aprofundar o debate do caráter revolucionário das Teses de Abril, compreendendo um pouco mais sobre o que Lênin entendia como o caminho para o socialismo naquele momento e o papel da centralização da produção nas mãos dos sovietes para garantir esse processo.

Palavras-chave: Teses de Abril. Lênin. Ditadura do proletariado. Revolução. Sovietes de Deputados Operários e Soldados.

Resumen: En este artículo, tenemos la intención de llevar a cabo un análisis de la octava tesis de abril, teniendo en cuenta el contexto en el que se la escribió. Para esto, buscamos utilizar el método del análisis inmanente o estructural chasiniano para comprender los conceptos principales tratados por Lenin sobre este punto. Por lo tanto, se propone profundizar el debate sobre el carácter revolucionario de las Tesis de Abril, entendiendo un poco más sobre lo que Lenin entendió como el camino hacia el socialismo en ese momento y el papel de la centralización de la producción en manos de los soviéticos para garantizar este proceso.

Palabras-clave: Tesis de Abril. Lenin. Dictadura del proletariado. Revolución. Sovietes de Diputados Operários y Soldados.

Abstract: In the present article, we intend to carry out an analysis of the eighth april thesis, taking into account the context in which it was written. Therefore, we seek to use the method of immanent or structural analysis of Chasin to understand the main concepts treated by Lenin on this point. Thus, it's purpose is to deepen the debate on the revolutionary character of the April Theses, understanding a little more about what Lenin understood as the path to socialism at that time and the role of centralization of production in the hands of the Soviets to guarantee this process.

Keywords: April Thesis. Lenin. Dictatorship of the proletariat. Revolution. Soviet of Workers' and Soldiers' Deputies.

\section{Introdução}

Como coloca José Paulo Netto em seu prefácio de Lenin e a revolução de outubro: Textos no calor da hora (1917-1923), a análise cuidadosa dos textos influentes na teoria tática bolchevique é essencial para a compreensão do processo revolucionário que se deu curso em 1917 (NETTO, 2017, p. 17-18). 
Partindo dessa percepção, a obra Sobre as tarefas do proletariado na presente revolução (ou as famosas Teses de Abril), escrita por Lênin ${ }^{3}$, torna-se então uma peça vital para a compreensão do que foi a revolução russa. As Teses foram escritas já nos dias 17 e 18 de abril, logo após o retorno do filósofo de seu exílio para Petrogrado em 16 de abril, tratando-se de dez teses nas quais ele esboça um planejamento para organizar o que entendia como o trabalho do proletariado rumo à vitória a partir do momento vigente, confrontando seus opositores no delinear de uma estratégia que logo seria hegemônica no partido (NETTO, 2017, p. 19).

Pretendemos, no presente artigo, analisar a supramencionada obra leniniana a partir da crítica imanente Lukácsiana ${ }^{4}$, que posteriormente Chasin chamou de análise imanente ou análise estrutural (CHASIN, 2009, p. 25). Desse modo, realizamos um recorte específico no ponto oito das Teses de Abril para aprofundarmos na análise sem cairmos "em uma análise meramente exegética, em que as ideias filosóficas parecem pairar no ar" (SARTORI, 2019, p. 12). Encontramos nesta oitava tese uma profundidade considerável, colocada pelo autor de modo relativamente simples, mas que apresenta conceitos extremamente complexos que pretendemos destrinchar com atenção. Compreendemos a oitava tese como um trecho muito importante para entender o caráter revolucionário das teses de Abril, e para começar a entender o que Lênin definiu como socialismo, o caráter que a política apresenta para o filósofo em meio ao alvoroço das revoluções de 1917, e quais são a natureza e o papel da centralização da produção nesse momento de construção do que ele entendia como ditadura do proletariado.

Na tese leniniana em análise, temos: "8. Nossa tarefa imediata não é 'introduzir' o socialismo, mas tão-somente passar imediatamente o controle da produção social e da distribuição dos produtos aos sovietes dos deputados operários." (LÊNIN, 1979, p. 27)". Como se pode perceber, portanto, um trecho que para um leitor desatento pode aparentar certas superficialidade e simplicidade, apresenta uma quantidade de conceitos complexos que compõem a teoria do filósofo de uma maneira. O quê Lênin quis dizer com socialismo? Por que, para ele, a centralização da produção social e da distribuição dos produtos deveria ser feita nas mãos dos SDO? Qual era o caráter dos SDO em abril de 1917 e qual a importância deles no que seria uma fase, para Lênin, prévia ao socialismo russo? Por que colocar agora importância da não introdução do socialismo como uma tarefa imediata? Essas são algumas das perguntas que tentaremos responder ou, ao menos, introduzir uma análise coerente no artigo que se segue.

\section{De que forma essa centralização ainda não é introduzir o socialismo para Lênin}

Neste momento da exposição, deteremos em explicitar três pontos centrais: a) explicitar o porquê que Lênin na oitava tese - assim como nas demais — não tem como necessidade imediata introduzir o chamado socialismo (LÊNIN, 1979, p. 27). Para isso, necessário remontar brevemente em textos contemporâneos do autor, principalmente em $\mathbf{O}$ Estado e a revolução em que o autor distingue o que ele tem por ditadura do proletariado, socialismo e comunismo. A resposta para a necessidade imediata colocada por Lênin está justamente na ditadura do proletariado, em que o controle e a produção se concentram nas mãos desta classe; b) compreender-se-á, então, de que modo no texto pretende-se realizar 
a tarefa de "passar imediatamente o controle da produção social e da distribuição dos produtos aos sovietes dos deputados operários.", assimilando o que eram os Sovietes de Deputados Operários e Soldados à época (LÊNIN, 1979, p. 27); e c) por fim, demonstrar-se-á como a necessidade imediata da construção do "Estado-Comuna" (LÊNIN, 1979, p. 28) não é o objetivo final, na medida em que o Estado precisa ser destruído. Mesmo que o fim do Estado não apareça, efetivamente, de maneira explícita nas Teses de Abril, é impossível não tratá-lo tendo em vista sua importância para o autor.

\section{a. Necessidade imediata}

Em que a construção do SDO se diferencia do socialismo para Lênin? Por que a centralização “do controle da produção e da distribuição dos produtos" (LÊNIN, 1979, p. 27) nas mãos destes não é, ainda, o socialismo?

Primeiramente, são necessários breves apontamentos. A compreensão de que forma a solução imediata de Lênin nas Teses de Abril se difere do socialismo perpassa, sem dúvidas, pelo próprio entendimento do autor sobre o que seria o Estado. Não pretendemos, aqui, esmiuçar toda a categoria de Estado em Lênin, mas, apenas, trazer breves apontamentos que permitirão elucidar o problema do tópico. Em seu notório livro $\mathbf{O}$ Estado e a revolução, Lênin assim classifica o Estado: "O Estado é o produto e a manifestação do caráter inconciliável das contradições de classe. O Estado surge onde, quando e na medida em que as contradições de classe não podem objetivamente ser conciliadas. E inversamente: a existência do Estado prova que as contradições de classe são inconciliáveis (LÊNIN, 2017, p. 29)". A clara influência, principalmente, de Marx e Engels e sua crítica da política aparece de maneira explícita no texto, conforme as próprias diversas citações feitas à Marx e Engels comprovam5. Logo após tal citação, inclusive, Lênin se remete justamente ao período logo após a revolução de fevereiro de 1917, afirmando que mencheviques e socialistas-revolucionários não compreenderam "a questão do significado e do papel do Estado." (LÊNIN, 2017, p. 29) Papel este que se seria justamente que “o Estado é um órgão de dominação de determinada classe, a qual não pode ser conciliada." (LÊNIN, 2017, p. 29)

No contexto em que as Teses de Abril foram produzidas - na "passagem da primeira etapa da revolução, que deu o poder à burguesia em função do insuficiente grau de consciência e organização do proletariado, à sua segunda etapa, que deve dar o poder ao proletariado." (LÊNIN, 1979, p. 22) - a questão era, pois, tomar o poder que se encontrava nas mãos da burguesia, e não conciliar com esta classe. Essa era a chamada tarefa imediata. Tarefa, esta, que foi chamada de ditadura do proletariado - a tarefa do proletariado era "estabelecer a ditadura do proletariado" (DEUTSCHER, 1966, p. 162) - tanto em comentários feitos por Lênin às Teses de Abril $^{6}$ como no próprio livro Estado e revolução. Em comentários às teses, Lênin afirma: "A ditadura do proletariado existe, mas não sabemos o que fazer dela." (LÊNIN, 1979, p. 27) No segundo, o autor se pronuncia da seguinte maneira: "a passagem da sociedade capitalista (...) para a sociedade comunista é impossível sem um "período de transição política" em que o Estado não pode ser outra coisa senão a ditadura revolucionária do proletariado" (LÊNIN, 2017, p. 112), sendo esta forma de organização a única capaz de "quebrar a resistência dos capitalistas exploradores." (LÊNIN, 2017, p. 114) 
Ainda sobre a chegada de Lênin em Abril e a defesa da necessidade imediata da ditadura do proletariado, necessário dois apontamentos: a) a defesa de Lênin, para a Rússia, antes de 1917 não era esta. Por mais que José Paulo Netto demonstre que mudança de pensamento de Lênin não se trata de uma inflexão teórica - "Esta nova projeção e sua implicação estratégica não foi produto de qualquer procedimento intuitivo nem surgiu de um repentino insight - ela veio sendo elaborada por Lênin desde a eclosão da guerra." (NETTO, 2017, pp. 35-36) —, fato é que até, pelo menos, 1914, Lênin deixava claro que a revolução não ocorreria em um país atrasado com a Rússia ${ }^{7}$. Porém, justamente com as Teses de Abril, Lênin convence-se plenamente que a Revolução Russa pode ser o imediato prólogo da revolução socialista mundial e o nexo entre a revolução socialista no Ocidente e a revolução democrática no Oriente, dinamizando o despertar da Ásia" (NETTO, 2017, pp. 35); b) Ademais, com tal mudança de posição se aproximava bastante com a própria posição de Trotsky, fato que gerou estranhamento, segundo Deutscher: "e a Rússia estava chamada a deflagrar a revolução socialista europeia. Isso era trotskismo, não leninismo resmungaram os leninistas — , mais uma vez referindo-se a velhas disputas." (DEUTSCHER, 2006, p. 163)

Porém, de que modo essa ditadura do proletariado, necessidade imediata colocada no contexto das Teses de Abril se diferencia do socialismo? Afinal, como afirma Lênin, "Nossa tarefa imediata não é 'introduzir' o socialismo.” (LÊNIN, 1979, p. 27) Por socialismo, Lênin, segundo O Estado e a revolução, refere-se ao que Marx denominou como primeira fase da sociedade comunista em a Crítica ao programa de Gotha. Neste, o próprio Lênin admite, indo de acordo com Marx, que "direito burguês não é abolido completamente, mas apenas em parte, na medida em que a revolução econômica for realizada." (LÊNIN, 2017, p. 119) Na mesma obra, Lênin afirma que "Os meios de produção deixam de ser, nesse momento, propriedade privada de indivíduos. Os meios de produção pertencem à sociedade inteira." (LÊNIN, 2017, p. 118) Mas, em que essa caracterização se difere do ponto colocado nas Teses de Abril que, segundo Lênin, não se trata do socialismo? Sendo ainda mais claro: Por que "passar imediatamente o controle da produção social e da distribuição dos produtos aos sovietes dos deputados operários" (LÊNIN, 1979, p. 27) não é tido como socialismo por Lênin?

A resposta para tal pergunta se dá na medida em que Lênin não vê, por assim dizer, o Estado na transição como um Estado; não é um Estado propriamente dito:

\footnotetext{
Mais adiante, no período de transição do capitalismo para o comunismo, a repressão é ainda necessária, mas uma maioria de explorados a exerce contra uma minoria de exploradores. O aparelho especial de repressão do "Estado" é ainda necessário, mas é um Estado transitório, já não um Estado propriamente dito ${ }^{8}$, visto que o esmagamento de uma minoria de exploradores pela maioria dos escravos assalariados de ontem é uma coisa relativamente tão fácil, tão simples e tão natural que custará à humanidade muito menos sangue que a repressão das revoltas de escravos, de servos e de operários assalariados. (LÊNIN, 2017, p. 116)
}

Ou seja, o "esmagamento de uma minoria de exploradores" ainda seria necessário. Assim, pois, não há como se reivindicar o socialismo no momento, na medida em que os sovietes precisam centralizar a produção em suas mãos; já que os meios de produção ainda não são pertencentes "à sociedade inteira" (LÊNIN, 2017, p. 118) - produção esta que se encontra, pois, nas mãos da burguesia em abril de 1917. Ao 
que parece, então, Lênin já apresenta nas Teses de Abril os germes do que ele desenvolveria profundamente em o Estado e Revolução. Mais que isso, a forte divisão apresentada pelo autor entre: i) ditadura do proletariado; ii) socialismo; e iii) comunismo já está presente - mesmo o autor não se referindo ao último explicitamente nas Teses de Abril.

Divisão, esta, que parece não ser tão importante em Marx. O autor apresenta a questão de uma maneira menos rígida na própria Crítica ao programa de Gotha. A própria distinção entre ditadura do proletariado e a primeira fase do comunismo não é tratada de maneira tão absoluta e explícita. Lênin parece deixar a questão nebulosa afirmando, em O Estado e a revolução, que: "não se pode pensar que, logo que o capitalismo for derrubado, as pessoas saberão, sem um tipo de Estado de direito, trabalhar para a sociedade.” (LÊNIN, 2017, p. 120) Em citação já apresentada anteriormente, Lênin admitiu explicitamente a existência do direito na primeira fase da sociedade comunista - "direito burguês não é abolido completamente, mas apenas em parte, na medida em que a revolução econômica for realizada" (LÊNIN, 2017, p. 119) —, inclusive com a função de "regulador (fator determinante) da repartição dos produtos e do trabalho entre os membros da sociedade." (LÊEIN, 2017, p. 120) Ou seja, Lênin afirma que nessa fase o controle e a produção não pode, como já afirmado, encontrar-se simplesmente nãos "mãos da sociedade inteira." (LÊNIN, 2017, p. 118) Agora, ainda se falando de Estado e Revolução a questão já aparece como um tipo de Estado de direito, ou seja, não apenas direito. Por fim, ao que parece, Lênin tem ciência da existência da esfera da política e do Estado ainda nessa fase, por mais que afirme se tratar de um não "Estado propriamente dito.” (LÊNIN, 2017, p. 116)

Ou seja, a distinção entre ditadura do proletariado e socialismo parece ser bastante frágil dentro do próprio pensamento de Lênin. Por mais que o autor tenha abordado essas três "etapas" em O Estado e a revolução - ou seja, mesmo ano em que escreveu as Teses de Abril — ao que parece, na distinção entre a ditadura do proletariado e o socialismo, Lênin parece não explicitar de maneira suficientemente clara a distinção e os efeitos as categorias da política e Estado nessas diferentes fases. Assim, por mais que traga a distinção já afirmada nas Teses de Abril entre socialismo e ditadura do proletariado, não há uma consequência tão clara dessa distinção.

Ademais, ainda sobre as teses, o ponto sobre o fim do Estado não aparece de maneira clara, como em O Estado e a revolução":

só o comunismo torna o Estado inteiramente supérfluo, porque não há mais ninguém a coagir - "ninguém" no sentido de classe social, no sentido de que não há mais luta sistemática a levar contra certa parte da população. (...) Mas, em primeiro lugar, não há para isso necessidade de uma máquina especial, de um aparelho especial de pressão; isso será feito pelo próprio povo armado tão simplesmente e tão facilmente como uma multidão civilizada. (LÊNIN, 2017, p. 116)

Questão que aparecia de forma diferente tendo em vista as necessidades imediatas no momento das Teses de Abril:

O que existe de original na atual situação russa é a passagem da primeira etapa da revolução, que deu o poder à burguesia em função do insuficiente grau de consciência e 
organização do proletariado, à sua segunda etapa, que deve dar o poder ao proletariado. (LÊNIN, 1979, p. 22)

Sobre o ponto do fim do Estado, impossível não citar o próprio Marx. Em diversos textos tais como Glosas marginais ${ }^{10}$, Miséria da filosofia ${ }^{11}$, Manifesto Comunista $^{12}$ e etc. - desde $1843^{13}$, Marx aborda como a esfera da política e, consequentemente, o próprio Estado devem ser destruídos com a destruição das relações de produção não só burguesas, mas de qualquer modo de produção que engendre uma sociedade dividida em classes. Tais apontamentos aparecem claros nos trechos analisados de Lênin, por mais que com suas devidas particularidades em relação ao próprio Marx.

Portanto, não é de se surpreender que Lênin não traga imediatamente a própria necessidade de superação completa do Estado. Necessário, agora, compreender qual a organização era defendida nesse contexto por Lênin.

\section{b. SDO}

Para uma melhor compreensão dos fatos e das definições acima trabalhadas, é necessário, então, entender de que se tratam os Sovietes de Deputados Operários e Soldados (SDO) colocados por Lênin no texto. Segundo John Reed, os sovietes surgiram em 1905,

quando, durante a primeira greve geral de trabalhadores, as fábricas de Petrogrado e as organizações sindicais enviaram delegados a um Comitê de Greve Central. Este Comitê de Greve foi chamado de Conselho dos Deputados dos Trabalhadores. Ele organizou a segunda greve geral no outono de 1905, enviou organizadores para toda a Rússia e, por um pequeno período de tempo, foi reconhecido pelo Governo Imperial como o portavoz autorizado da classe trabalhadora revolucionária da Rússia. (REED, 2018)

A revolução de 1905 foi ferozmente derrotada e os líderes do Conselho que seria o primeiro soviete fugiram ou foram presos, dentre eles o próprio Trotsky ${ }^{14}$. A organização dos trabalhadores em sovietes se difere da organização tradicional europeia em sindicatos, visto que, como coloca Gramsci, os sindicatos, apesar de poderem oferecer ao proletariado uma "burocracia experimentada", dentre outros benefícios, são de natureza concorrencial, e não comunista. Já os conselhos de fábrica, de onde derivam os sovietes, representam todos os ramos do trabalho de acordo com sua contribuição e portanto "sua razão de ser está no trabalho, está na produção industrial, quer dizer num facto permanente e não no salário, na divisão das classes, quer dizer num facto transitório que se trata precisamente de ultrapassar." (GRAMSCI, 1976, p. 54) $\mathrm{Na}$ realidade russa, os sindicatos formato tinham um papel ainda mais fraco, tendo sido importados por intelectuais de acordo com os modelos alemães e franceses, reforçando seu papel secundário na revolução e na organização dos trabalhadores russos. (REED, 2018)

Os SDO em 1917 funcionavam através da eleição direta de acordo com atribuições e necessidades de cada localidade, porém, desde pelo menos junho quando ocorreu o Primeiro Congresso dos Sovietes de Deputados Operários e Soldados de toda a Rússia ou até antes, as eleições tinham a restrição de um deputado ser eleito por pelo menos quinhentos trabalhadores, para que não houvesse um número ingovernável de deputados. Segundo Reed, "os dois primeiros Congressos de Soviets de toda a Rússia foram organizados com a eleição de mais ou menos 1 delegado a cada 25.000 eleitores mas, na 
verdade, os delegados representavam distritos de tamanhos variado." (REED, 2018) Além disso, "Até fevereiro de 1918, qualquer um poderia votar nos delegados dos Soviets. Até burgueses foram aceitos, quando se organizaram e exigiram representação nos Soviets.” (REED, 2018)

Em sua primeira carta das conhecidas Cartas de longe, intitulada A Primeira Etapa da Primeira Revolução, datada de 21 a 22 de março (de acordo com as datas padrão do calendário ocidental) Lênin coloca que os SDO são a base para a revolução de 1917 triunfar, diferentemente do que havia ocorrido em 1905:

O Soviete de Deputados Operários é a organização dos operários, o embrião do governo operário, o representante dos interesses de todas as massas pobres da população, isto é, de $9 / 10$ da população, que luta pela paz, pelo pão, pela liberdade.(...) A luta destas três forças determina a situação que se apresenta agora e que constitui a transição da primeira etapa da revolução para a segunda. (LÊENIN, 1986)

Em 25 de Março (de acordo com o calendário ocidental), em sua carta nomeada Como Alcançar a Pą?, também conhecida como a quarta carta das Cartas de longe, Lênin já fala sobre a importância dos SDO como base do êxito da tomada do poder pelo povo. Nela, ele coloca que os sovietes de deputados operários, soldados e camponeses de toda Rússia, tomado o poder de Estado, aplicariam um programa de paz no qual se colocariam "de acordo em travar uma guerra contra qualquer governo burguês e contra todos os governos burgueses do mundo, porque seria uma guerra realmente justa, porque todos os operários e trabalhadores de todos os países contribuiriam para o seu êxito." (LÊENIN, 1986) Essa seria mais uma das razões para que o poder de Estado nas mãos dos SDO seria fundamental para a construção da alternativa socialista no futuro.

No Primeiro Congresso dos Sovietes de Deputados Operários e Soldados de toda a Rússia, já em junho de 1917, aproximadamente 2 meses depois da escrita das Teses de Abril, Lênin disserta, em seu Discurso Sobre a Atitude em Relação ao Governo Provisório, sobre a autenticidade dos sovietes, que não poderiam existir ao lado de um governo burguês. Para ele, os SDO representam um "tipo novo e mais democrático de Estado (...) na qual o poder pertence exclusivamente aos Sovietes de deputados operários e soldados." (LÊNIN, 2009)

A partir dessa leitura, conseguimos compreender um pouco mais sobre o que Lênin coloca como o papel do controle dos SDO sob a produção social e da distribuição dos produtos na oitava tese. O poder do Estado deveria passar, então, para as mãos dos SDO enquanto representantes das massas pobres da Rússia para consolidar a ditadura do proletariado, como também foi colocado por lênin em outras partes Teses de Abril. Os SDO seriam então "a única forma possível de governo revolucionário", e a tarefa a partir do início de Abril seria em colocar para as massas os erros da tática de aliança com a burguesia do governo daquele momento. Seria necessário desenvolver então esse trabalho de crítica ao governo vigente, reforçando a necessidade de o poder ser todo dos SDO. "Escrevo, leio e mastigo: 'Os Sovietes de DO são a única forma possível de governo revolucionário e, por isso, a nossa tarefa só pode consistir em explicar os erros da sua táctica de modo paciente, sistemático, tenaz, e adaptado especialmente às necessidades práticas das massas...’." (LÊNIN, 1979, p. 24) 
Nos comentários feitos posteriormente (ainda que no mesmo mês) por Lênin nas Teses, o filósofo reforça, ainda, sua tese de que o Estado cujo poder está nas mãos dos SDO não é o socialismo em si, como debatido anteriormente neste artigo, mas "um passo em direção ao socialismo". Esse seria, então, o grande diferencial da revolução que estava por vir das tentativas passadas de revolução no início do século na Rússia "Não prometemos libertar [...] mas afirmamos que isso só é possível por meio desta forma (soviete dos deputados operários e soldados). Nenhum governo, salvo o soviete dos soviete dos deputados operários e assalariados agrícolas." (LÊNIN, 1979, p. 26)

Desse modo, está mais claro agora o caráter dos sovietes em abril de 1917, tais como abordados por Lênin na oitava tese, objeto de nosso estudo em questão. Entendemos melhor, portanto, o que Lênin quis dizer também com a não introdução do socialismo enquanto tarefa imediata, o qual se diferencia de "passar imediatamente o controle da produção social e da distribuição dos produtos aos sovietes dos deputados operários.” (LÊNIN, 1979, p. 27)

\section{c. Centralização do controle e distribuição (fim da política?)}

Resta, agora, compreender qual o objetivo da passagem imediata do "controle da produção social e da distribuição dos produtos" (LÊNIN, 1979, p. 27) nas mãos dos SDO. A resposta para isso está ligada ao próprio fim do Estado exposto por Lênin, principalmente em $\mathbf{O}$ Estado e a revolução, mesmo que este fim não apareça explicitamente nas Teses de Abril. Basicamente, as teses trazem um programa imediato que se refere a centralização de dois setores da produção: a) a propriedade fundiária e rural; b) a propriedade financeira. Tal centraliza, tem, por óbvio, transformar o SDO não só apenas em detentor do poder político, mas também do próprio controle da esfera de produção. Controle, este, que se encontra sobre a primeira, nas palavras do próprio Lênin na sexta tese:

No programa agrário, transportar o centro de gravidade sobre os sovietes dos deputados de assalariados agrícolas. Confisco de todas as terras dos grandes proprietários. Nacionalizar todas as terras do país e pô-las à disposição dos sovietes locais de deputados e assalariados agrícolas e de camponeses pobres. (...) Transformação de todo latifúndio (...) em uma exploração-modelo colocada sob o controle dos deputados dos assalariados agrícolas e funcionando para a coletividade." (LÊNIN, 1979, p. 26, comentários).

Há, imediatamente, a clareza da questão: todas as terras do país, inclusive as confiscadas, seriam nacionalizadas. Esse processo de nacionalização seria, justamente, a passagem do controle da propriedade agrária para as mãos dos SDO. Porém, ao mesmo tempo, se os SDO são caracterizados na própria oitava tese como "sovietes dos deputados operário" (LÊNIN, 1979, p. 27) - e estes devem deter o "controle da produção social e da distribuição dos produtos" (LÊNIN, 1979, p. 27), aparece, agora, uma distinção entre o SDO e os assalariados agrícolas e camponeses pobres. Ao que parece, pois, Lênin coloca uma distinção entre os próprios deputados operários e os deputados de assalariados agrícolas e de camponeses pobres. Mais do que isso, estes dois também aparecem como componentes distintos da sociedade russa. É interessante, ainda, notar o modo pelo qual Lênin traz a palavra "assalariados" se referindo aos camponeses. Continuemos na análise para compreender melhor esses pontos. 
Nos comentários feitos pelo próprio Lênin as teses, o autor traz elucidações sobre o ponto: $\mathrm{O}$ que é o campesinato? Não sabemos, não existem estatísticas, mas sabemos que é uma força. (LÊNIN, 1979, p. 26) Os motivos dessa imprecisão são dados pela citação anteriores. Lênin, abstratamente, apresentava uma solução para concentrar a produção do campo nas mãos do poder político do operário. Porém, como elaborar isso de maneira concreta se desconhecia quase que completamente essa classe?

(...) se eles tomam a terra, estejam certos de que não entregarão, eles não a pedirão a nós. O eixo do programa deslocou-se, o centro de gravidade do programa são os sovietes de deputados dos assalariados agrícolas. Se o camponês russo não decide a sorte da revolução, será o operário alemão quem decidirá. (...) Mesmo que déssemos a terra a este último (assalariados agrícolas), ele não organizaria uma roça. Tomaremos a terra e o grande proprietário não poderá mais recuperá-la. Exploração da terra sobre bases coletivas (LÊNIN, 1979, p. 26, grifos nossos).

Analisar a complexidade da questão do campo na conjuntura de 1917 da Rússia não é nossa tarefa. O que nos interessa aqui são dois aspectos principais: o primeiro é o modo ainda bastante abstrato que a questão é trazida pelo próprio Lênin, tendo em vista o desconhecimento da realidade do campo à época; ademais, o caráter de distinção entre o SDO e os assalariados agrícolas torna-se ainda mais latente. Do grifo da citação, destaca-se o modo como, em uma situação hipotética, a terra seria dada "déssemos" - pelos SDO aos assalariados agrícolas. Ao que parece, estes, pois, seriam assalariados do próprio Estado-Comuna inicialmente. Assim, o próprio Lênin parece ter ciência do modo como a necessidade imediata anunciada na oitava tese ainda não seria plenamente capaz de unificar toda a produção nas mãos de todos os indivíduos - este o objetivo final trazido em $\mathbf{O}$ Estado e a revolução. O poder política se encontraria nas mãos dos SDO que ainda se colocariam em distinção aos próprios camponeses e assalariados agrícolas.

Assim, a necessidade imediata trazida na oitava tese seria, ainda, bastante limitada para se alcançar a segunda etapa do comunismo, já explicitada brevemente. Há, pois, o modo como o próprio Lênin parece perceber que a tarefa imediata seria limitada, e ao mesmo tempo necessária, ao trazer uma "exploração-modelo colocada sob o controle dos deputados dos assalariados agrícolas e funcionando para a coletividade." (LÊNIN, 1979, p. 27) Esses assalariados controlariam a produção agrícola, tendo em vista sempre a coletividade, mas ao mesmo tempo apareceriam, ainda, dominados pelos próprios sovietes dos deputados operários.

Sobre a questão dos bancos, Lênin assim afirma na sétima tese: “7. Fusão de todos os bancos do país em um só banco nacional, posto sob o controle dos sovietes dos deputados operários.” (LÊNIN, 1979, p. 27) A destruição imediata da burguesia financeira, pois, encontrava-se como necessidade imediata para o revolucionário. Como vislumbrar o "controle da produção social e da distribuição dos produtos" nas mãos dos SDO permitindo a existência de bancos privados? Em comentários sobre a tese anterior, Lênin afirma que:

O banco é "uma forma de contabilidade social" (Marx). A guerra ensina economia, todos sabem que os bancos pilham as economias do povo. Os bancos constituem o nervo, o centro da economia. Não podemos tomar os bancos em nossas mãos, mas proporemos sua fusão sob o controle dos sovietes dos deputados operários. (LÊENIN, 1979, p. 27) 
Ao mesmo que o autor vê a impossibilidade da expropriação completa e imediata de todos os bancos, ele encontra como saída a fusão destes. Uma solução, de certa forma, menos radical do que a proposta à questão da propriedade fundiária vista anteriormente.

A omissão em relação à propriedade industrial urbana deve, também, ser destacada. O tratamento apenas das questões dos bancos e do campo, de certa forma, não é uma "inovação" do autor. Os próprios Marx e Engels em o Manifesto do Partido Comunista não trazem dentre as 10 medidas revolucionárias a expropriação/confisco da propriedade industrial urbana, mesmo salientado a necessidade da "Multiplicação das fábricas nacionais e dos instrumentos de produção (ENGELS; MARX, 2010, p. 58)." Não se pode abordar completamente o ponto, por mais que defendamos que o não tratamento pelos três autores da necessidade imediata de se atacar e defrontar-se imediatamente contra a burguesia industrial15, devido ao fato de que esta classe domina imediatamente as forças produtivas centrais urbanas e, de certa forma, em sua parte mais radical, tem também como interesse a própria estatização da propriedade do campo e o combate a exploração da burguesia financeira (SARTORI, no prelo).

O que se destaca, por fim, é o modo como efetivamente as necessidades imediatas trazidas nas Teses de Abril da centralização da produção e da distribuição nas mãos dos SDO são, efetivamente, imediatas. Lênin não via nesta centralização nas mãos do Estado-Comuna como o fim do processo. O ponto do fim do Estado e da própria política não são explicitamente afirmados nas Teses de Abril. Porém, em um texto próximo — O Estado e a revolução — o autor afirma que “Ao mesmo tempo, só na sociedade comunista que o Estado “deixará de existir e será possível falar de liberdade.”[sic] a expressão o Estado definha é muito feliz porque exprime ao mesmo tempo lentidão do processo e sua espontaneidade.” (LÊEIN, 2017, p. 115)

\section{Conclusão}

Em síntese, viu-se o modo como as questões dos sovietes dos deputados operários, da centralização da produção, a política e a revolução se engendram, tendo como parâmetro a oitava tese de Lênin, do documento que ficou conhecido como Teses de Abril. Imediatamente regressando à Rússia em meio ao processo revolucionário iniciado em fevereiro de 1917, Lênin traz a tomada do poder político pelo proletariado como uma realidade imediata, defendo uma revolução de caráter proletariado e a ditadura desta classe. Com isso, busca centralizar as forças produtivas e meios de produção nas mãos dos sovietes deputados operários, em aliança com os camponeses, para destruir a classe burguesa. Porém, tendo em vista as próprias especificidades do contexto russo, viu-se que o modo de ação em relação a cada setor produtivo seria diferente: Lênin não universaliza a ação nem mesmo dentro dos limites nacionais russos em relação às diversas burguesas e classes presentes. Imediatamente, o autor visa compreender as especificidades tanto do campo como da esfera financeira e industrial.

Assim, além de trazer a possibilidade da revolução proletária para países periféricos e com o capitalista ainda não plenamente desenvolvidos, Lênin traz um programa conciso e decisivo para o processo revolucionário russo, não se esquecendo que pontos muito caros ao marxismo: a necessidade de 
se compreender as particularidades, e não buscar modelos prontos e pré-definidos e a importância da atuação na esfera política, mas como um meio transformador da realidade econômica e social; para a construção de uma nova forma de sociabilidade, o comunismo.

\section{Referências:}

GRAMSCI, Antonio. Democracia operária: partido, sindicatos e conselhos. Tradução A. Gil. Coimbra: Editora Centelha, 1976.

CHASIN, José. Determinação ontonegativa da politicidade. Verinotio - revista on-line de filosofia e ciências humanas, n. 15, ano VIII, pp. 42-59, abr. 2012.

DEUTSCHER, Isaac. Stalin: uma biografia política. Tradução Luiz Sérgio Henriques. Rio de Janeiro: Civilização Brasileira, 2006.

ENGELS, Friedrich; MARX, Karl. Manifesto Comunista. Organização e introdução Osvaldo Coggiola e tradução de Álvaro Pina e Ivana Jinkings. - São Paulo: Boitempo, 2010.

KRAUSZ, Tamás. Reconstruindo Lenin: uma biografia intelectual. São Paulo: Editora Boitempo, 2017.

LÊNIN, Vladmir. Cartas de Longe. Edições Avante: 1986. Disponnível em: $<$ https://www.marxists.org/portugues/lenin/1917/03/20.htm> Acesso em junho de 2020.

LÊNIN, Vladmir. Discurso Sobre a Atitude em Relação ao Governo Provisório. Primeiro Congresso dos Sovietes de Deputados Operários e Soldados de toda a Rússia. Edições Avante: 2009. Disponível em: $<$ https://www.marxists.org/portugues/lenin/1917/06/17.htm>. Acesso em junho de 2020.

LÊNIN, Vladmir. O Estado e a revolução. Tradução de Paula Almeida. São Paulo: Boitempo, 2017.

LÊNIN, Vladmir. Teses de abril. Tradução Jean-Jaques Marie. In Lenin, V; Trotski, L. A questão do programa. Tradução Francisco Solano. São Paulo: Kairos, 1979.

LUKÁCS, György. El asalto a la razón: la trayectoria del irracionalismo desde Scheilling hasta Hitler. Cidade do México: Fondo de Cultura Económica México - Buenos Aires, 1959.

LUKÁCS, György. Os princípios ontológicos fundamentais de Marx. São Paulo: Editora Ciências Humanas LTDA, 1972.

MARX, Karl. Miséria da filosofia. Tradução de José Paulo Netto. São Paulo: Boitempo, 2017.

MARX, Karl. Luta de classes na Alemanha. Tradução Nélio Schneider. São Paulo: Boitempo, 2010.

NETTO, José Paulo. Prefácio. In: Lenin e a revolução de outubro: Textos no calor da hora (1917-1923) São Paulo: Expressão Popular, 2017.

REED, John. Os sovietes em ação. Editora Nova Cultura: 2018. Disponível em:

$<$ https://www.novacultura.info/single-post/2018/05/04/Os-sovietes-em-acao $>$. Acesso em junho de 2020.

TROTSKY, Leon. A história da Revolução Russa. Tradução de E. Huggins. Brasília : Senado Federal, Conselho Editorial; Ed. do centenário, 2017.

SARTORI, Vitor. Ontologia nos extremos. São Paulo: Intermeios, 2019

SARTORI, Vitor. A relação cidade-campo em Marx: o capital, a renda da terra e o lucro (No prelo). 


\section{Notas}

1 Graduanda em direito na Universidade Federal de Minas Gerais (UFMG). Currículo na Plataforma Lattes:http://lattes.cnpq.br/5563010309423461. Orcid: https://orcid.org/0000-0002-8477-8578. E-mail: anamarra7@gmail.com.

2 Graduando em direito na Universidade Federal de Minas Gerais (UFMG). Currículo na Plataforma Lattes:http://lattes.cnpq.br/3221995324034812. Orcid: https://orcid.org/0000-0002-1762-2186. juliomotta1995@gmail.com

3 Sobre a vida de Lênin (cf. KRAUS, 2017). Ademais, o próprio estudo das obras de Lênin deve ter sempre o cuidado de que, como afirma Lukács, "Por mais correta que fosse a acentuação das novidades trazidas por Lenin, tal acentuação — no período de Stalin - teve cada vez mais o efeito de colocar lentamente o estudo de Marx em segundo plano e de trazer para o primeiro o estudo de Lenin (LÚKÁCS, 1972, p. 33)."

${ }^{4}$ Sobre a crítica imanente (cf. LUKÁCS, 1959).

${ }^{5}$ Infelizmente, as diferenças e semelhanças entre a questão da política do próprio compreendidas por Marx, Engels e Lênin não poderão ser tratadas com toda a exatidão que necessitam.

${ }^{6}$ Comentários estes feitos durante o "discurso pronunciado por Lenin na sessão de encerramento da reunião plenária dos representantes bolcheviques à Conferência Pan-Russa dos Sovietes de Delegados Operários e Soldados, que estava sendo realizada em Petrogrado “4 de abril de 19170”. (LÊNIN, 1979, p. 17). A própria nota da tradução acrescenta que o relatório taquigráfico é "às vezes incompleto e pouco compreensível.".

7 Em suma : "Lenin identificava-o como instaurando uma situação revolucionária - e visualizava nesta situação a possibilidade concreta da revolução proletária nos países capitalistas à época desenvolvidos, revolução que abriria a via ao socialismo. (...) Importa ressaltar que Lenin, até aqui seguindo rigorosamente as concepções de Marx e Engels, prospectava essa revolução numa perspectiva mundial e emergindo "nos paises avançados" (desenvolvidos) - e, para ele, a Rússia tstarista não se incluía entre tais "países avançados". (NETTO, 2017, p. 34)

8 Afirmação é muito mais de Lênin que do próprio Marx.

${ }^{9}$ Só na sociedade comunista que o Estado "deixará de existir e será possiviel falar de liberdade. (...) a expressão o Estado definha é muito feliz porque exprime ao mesmo tempo lentidão do processo e sua espontaneidade (LÊNIN, 2017, p. 115)."

10 “A revolução como tal - a derrubada do poder constituído e a dissolução das relações antigas - é um ato político. No entanto, sem revolução o socialismo não poderá se concretizar. Ele necessita desse ato político, já que necessita recorrer à destruição e à dissolução. Porém, quando tem início a sua atividade organizadora, quando se manifesta o seu próprio fim, quando se manifesta a sua alma, o socialismo se desfaz do seu invólucro político (MARX, 2010, p. 52, grifos nossos)."

11 "Quererá isto dizer que depois da queda da antiga sociedade haverá uma nova dominação de classe, resumindo-se num novo poder político? Não (MARX, 2017, p. 147).”

12 "Quando, no curso do desenvolvimento, desaparecerem os antagonismos de classes e toda a produção for concentrada nas mãos dos indivíduos associados, o poder público perderá o caráter político (ENGELS, MARX, 2010, p. 59).”

13 "Em suma, à época de $A$ Gazeta Renana, Marx está vinculado às estruturas tradicionais da filosofia política, ou seja, à determinação ontopositiva da politicidade (CHASIN, 2012)."

14 Para mais informações, ver em (cf. TROTSKY, 2017)

15 Segundo Deutscher "A indústria não podia ser socializada imediatamente, mas a produção e a distribuição deviam ser postas sob controle operário (DEUTSCHER, 2006, p. 162).” 